
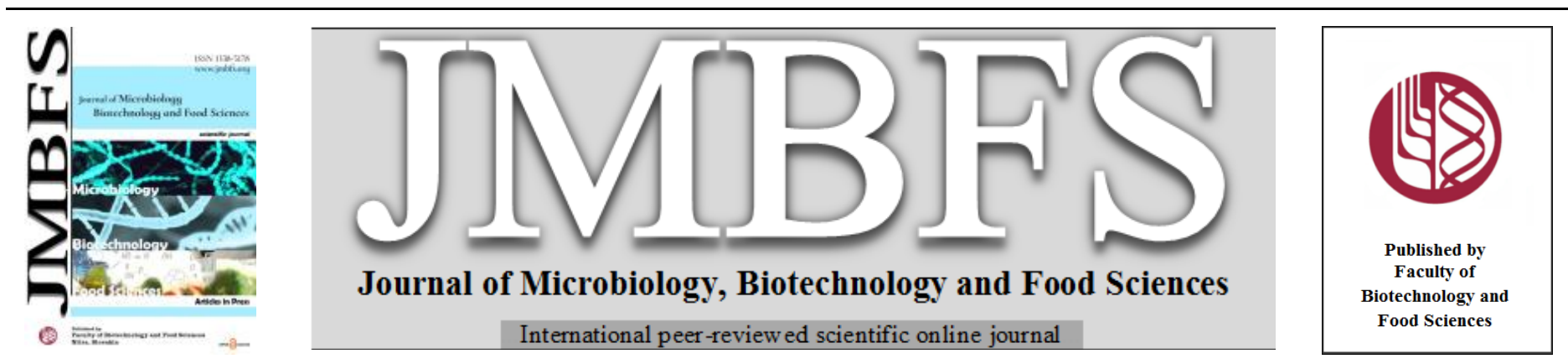

\title{
NUTRITIONAL COMPOSITION, BIOLOGICAL ACTIVITY AND TECHNOLOGICAL PROPERTIES OF NEW SLOVAKIAN BLACK OAT VARIETIES
}

\author{
Matej Čech ${ }^{1}$, Eva Ivanišová2 ${ }^{*}$, Peter Hozlár ${ }^{3}$, Marian Tokár ${ }^{4}$, Grzegorz Zagula ${ }^{5}$, Dorota Gumul ${ }^{6}$, Miroslava Kačániová ${ }^{5,7}$, Monika \\ Sterczyńska ${ }^{8}$, Peter Haščik
}

Address(es):

${ }^{1}$ Slovak University of Agriculture in Nitra, Faculty of Biotechnology and Food Sciences, Department of Technology and Quality of Animal Products, Tr. A. Hlinku 2, Nitra, Slovakia, SK-949 76.

${ }^{2}$ Slovak University of Agriculture in Nitra, Faculty of Biotechnology and Food Sciences, Department of Technology and Quality of Plant Products, Tr. A. Hlinku 2, Nitra, Slovakia, SK-949 76.

${ }^{3}$ National Agricultural and Food Centre, Research Institute of Plant Production, Research and Breeding Station, Vígl'aš-Pstruša, Slovakia, SK- 96202.

${ }^{4}$ Bakery Jozef Oremus, Štúrova 43, Bánov, Slovakia, SK-941 01.

${ }^{5}$ University of Rzeszow, Faculty of Biology and Agriculture, Department of Bioenergetics and Food Analysis, Zelwerowicza 4, Rzeszow, Poland, PL-35-601.

${ }^{6}$ University of Agriculture in Krakow, Faculty of Food Technology, Department of Carbohydrate Technology, Balicka 122, Krakow, Poland, PL-30-149.

${ }^{7}$ Slovak University of Agriculture in Nitra, Faculty of Horticulture and Landscape Engineering, Department of Fruit Science, Viticulture and Enology, Tr. A. Hlinku 2, Nitra, Slovakia, SK- 94976.

${ }^{8}$ Koszalin University of Technology, Faculty of Mechanical Engineering, Śniadeckich 2, Koszalin, Poland, PL- 75-453.

*Corresponding author: eva.ivanisova@uniag.sk

https://doi.org/10.15414/jmbfs.4238

\section{ARTICLE INFO}

Received 20. 1. 2021

Revised 18. 7. 2021

Accepted 5. 8. 2021

Published 1. 12. 2021

Regular article OPEN $\partial_{\text {ACCESS }}$

\begin{abstract}
Black and red cereal grains, rich in anthocyanins, have recently gained a lot of interest in the food industry due to health benefits. The aim of this study was to evaluate the nutritional composition (crude protein, starch, ash, fat, $\beta$-glucans), biological activity (antioxidant activity, total polyphenols, carotenoids and anthocyanins) and technological properties (farinograph, amylograph and extensograph) of new Slovakian black oat varieties Hucul and Norik. Technological properties were observed by incorporation of whole-grain oatmeal flour to standard wheat flour T-650 in amount 3,6 and 9\%. The grains of selected varieties were grinded and resulting whole-grain oatmeal flour was used for analyses. The crude protein content was in both varieties in amount $\sim 11 \%$; starch content $\sim 44 \%$ and ash content in amount $\sim 2.6 \%$. The Norik variety showed a higher content of fat $-5.80 \%, \beta$-glucans $-4.29 \%$, and total carotenoids -7.47 $\mu \mathrm{g} \cdot \mathrm{g}^{-1}$. In Hucul variety was detected a higher content of total polyphenols $-0.19 \mathrm{mg}$ GAE. $\mathrm{g}^{-1}$ (GAE - gallic acid equivalent) and anthocyanins $-22.00 \mu \mathrm{g} \cdot \mathrm{g}^{-1}$. The antioxidant activity (DPPH method) was approximately at the same level in both evaluated varieties $3 \mathrm{mg}$ TEAC. $\mathrm{g}^{-1}$ (TEAC - Trolox equivalent antioxidant capacity). There were several differences in mineral composition between observed varieties. The Norik variety showed higher content $\left[\mathrm{mg} .100 \mathrm{~g}^{-1}\right]$ of $\mathrm{Fe}-5.94, \mathrm{~K}-397.56, \mathrm{Na}-6.33$ and $\mathrm{P}-365.51$, while in Hucul variety it was detected higher content of $\mathrm{S}-142.89$ and $\mathrm{Zn}-2.05$. Other mineral compounds were not significantly different. Amylograph device shown that with an increasing addition of black oat flour, the amylograph maximum fell down with the best value at 9\% addition with compared to standard flour - 1593 AU. Farinograph values on the contrary, showed the good quality of standard flour but parameter water absorption was better with addition of oat flour due to non-starch polysaccharides presented in oat. Extensograph device showed that increasing addition of oat flour decreased resistance to extension. Colorant cereals generally can increase biodiversity in agriculture, and can be attractive raw materials for production foods with added value.
\end{abstract}

Keywords: Avena sativa L, antioxidant activity, rheology, anthocyanins, mineral compounds

\section{INTRODUCTION}

FAO estimated, that world cereal production will reach 2,719 million tonnes in 2019, what is almost 62 million tonnes $(2.3 \%)$ above the production in 2018 (FAO, 2020a). However, following a significant demand slowdown caused by COVID-19 in early 2020, forecast to regain momentum in total utilization of coarse grains (which include oats) is in 2020/2021. Moreover, it would still remain below global production for a second consecutive season, what leads to higher stock levels and therefore lower international prices (FAO, 2020b).

Oat is minor, less cultivated, predominantly a European and North American crop. As they have cool moist climate; Russia, Canada, the United States, Finland, and Poland are leading oat producing countries. Oats have been used as livestock and human foods since ancient times (Varma, Bhankharia and Bhatia, 2016). The most economically important species - Avena sativa $\mathrm{L}$, is widespread throughout the world. Red oats (A. byzantina C. Koch.) are grown in southern Europe, mainly in Spain and Portugal, but also in northern Africa, south-western Asia, South America and Australia. A. strigosa Schreb (cultivars in Europe and Brazil, landraces on European islands) and A. abyssinica Hochst are grown to a lesser extent at regional level. One species, A. fatua, is considered an invasive weed. Seven of the wild species of the genus Avena are endemic and most endangered (Boczkowska, Podyma and Lapiński, 2016). Black oats are an upright, winter annual member of the Poaceae family, which reaches a height of $0.75-1.5 \mathrm{~m}$, depending on growing conditions. The leaves are flat, rough and numerous. The primary panicle branches droop with pendulous spikelets. Spikelets usually have two fertile florets with multiple awns, while the primary awn is straight, black and $1.7-3.5 \mathrm{~cm}$ long. Black oat sexually reproduces a hairy caryopsis (Clayton et al., 2014).

According to FAOSTAT (2020), world oats production in 2018 reached 23.05 million tonnes, whereas EU28 made up 7.74 million tonnes. Depending on the regions of the world, oats are grown primarily for grain, pasture, fodder and bedding, or as a pre-crop that improves soil properties. It is a traditional feed for horses, but is also used in the nutrition of calves and young animals, as well as poultry and sheep (Marshall $\boldsymbol{e t}$ al., 2013). Only 10\% of the oats produced are used for human consumption. In recent years, oat grain and its products belong to the group of modern, healthy and functional foods (Andersson and Börjesdotter, 2011). This might be a reason why oat have attracted attention 
from many researchers and also have increased interest of food industry in using oats as food ingredient in various food products as infant foods (Valle $\boldsymbol{e t} \boldsymbol{a l}$. 1981), bread (Zhang et al., 1998), oat milk (Önning et al., 1999), beverages (Gupta, Cox and Abu-Ghannam et al., 2010), breakfast cereals (Ryan, Thondre and Henry, 2011) and biscuits (Ballabio et al., 2011).

Oat is well known for its unique protein composition with good nutritional value; their content is between $11-15 \%$. Compared to other cereal proteins, oats are special in the structural properties and also in distribution of protein fractions (Klose et al., 2009). Their proteins are mainly comprised of globulins and therefore have a more balanced amino acid profile than other cereals. Oat proteins were thoroughly studied mainly because of their importance in horses' nutrition (Shewry, 1999; Shotwell, 1999). It was reported that thanks to its unique protein composition oats can be tolerated for most individuals with the celiac disease (Størsrud et al., 2003; Pulido et al., 2009). Although it has some wheat-like sequences in its protein structure, these are less frequent in oats. On the other side, there is no unambiguous consensus among scientists and nutrition experts on whether oats can be definitely recommended for patients with celiac decease (Kaukinen $\boldsymbol{e t}$ al., 2013). Oat is also highly valued cereal due to its high energy and nutritional value resulting from high fat content and the unsaturated fatty acids, in particular. On the other side, oat products are more susceptible to oxidation and swelling (Vollmanová et al., 2018).

The positive benefits of consumption, especially in whole grain forms, are partly attributed to $\beta$-glucans, which have excellent functional and nutritional properties (Gracia et al., 2017). $\beta$-glucans are indigestible fibres that form a viscous gel in the gastrointestinal tract. They are approved by the US Food and Drug Administration as LDL cholesterol lowering agents at dosage 3 g.day $^{-1}$ (Jenkins et al., 2002). High viscosity of oat $\beta$-glucans, even at low concentrations (1\%), is believed to delay gastric emptying, slow intestinal transit and thereby delay glucose and sterol absorption, which may contribute to lowering plasma glucose and insulin levels as observed in individuals with type 2 diabetes (Butt $\boldsymbol{e t}$ al. 2008). However, in study of Frid et al. (2017), general positive effect of $\beta$ glucan before meals on glucose control or variability in type 2 diabetes was not demonstrated. Nevertheless, adequate intake of dietary fibre is good prevention of obesity and World Health Organization recommends a daily intake of at leas $25 \mathrm{~g}$; however average intake is only $12-18 \mathrm{~g}$ in the USA and $15-20 \mathrm{~g}$ in Europe, but 40 - $60 \mathrm{~g}$ in Africa (Sterna, Zute and Brunava, 2016).

In the oat, several substances with antioxidant activity are present in larger quantities. The soluble fibre components, the high content of butyric acid in oat and the antioxidant properties of the tocorienols and phenolic compounds present in its grain can decisively inhibit the development of colon tumors. In addition, the oat contains a wide range of other antioxidants with a beneficial effect. These components, which include, in particular, avenantramides, may have othe substances in addition to the antioxidant effect. Bioactive agents in oat also include lignins, saponins, polyphenol substances and isoflavonoids, which may reduce the risk of cancer (Prugar $\boldsymbol{e t}$ al., 2008). Avenantramides are phenolic compounds that are found only in oats with anti-inflammatory effects and the initiation of natural cell death - apoptosis (as opposed to necrosis where a cell is violently destroyed and its contents may endanger surrounding cells) (Pridal $\boldsymbol{e}$ al., 2018). In the study of healthy people, avenantramides in conjunction with polyphenols in oats caused an increase in serum superoxide dismutase and reduced glutathione hormones by 8.4 , respectively $17.9 \%$ and potentially mutagenic malondialdehyde reduction of $28.1 \%$. Total cholesterol, triglycerides, and LDL cholesterol decreased by $11.1 \%, 28.1 \%$, respectively. $15.1 \%$ while HDL cholesterol increased by $13.2 \%$ (Liu, Zou and Wang, 2011).

Black oat is a potential source of natural colorants such as carotenoids and anthocyanins. Carotenoids are fat-soluble bioactive ingredients responsible for yellow, orange and red colors in various fruits, flowers and vegetables. Generally they are less important ingredients of cereals, but their high consumption cover this shortage. Some cereals have even higher amounts of carotenoids than found in fruits and vegetables (Hussain et al., 2015). Zeaxanthin is the dominan carotenoid in corn, while lutein is a major component of oat, barley, spelled and durum wheat. However, there are few studies on carotenoid content in oat and barley (Ndolo and Beta, 2013). Anthocyanidins and their glycosides anthocyanins, are among the most widespread plant pigments. These include e.g. pelargonidine, cyanidine, peonidine, delfinidine, petunidine and malvidine, which are responsible for the color of the flowers, fruits, cereals and products made from them. Anthocyanin pigments are characterized by high biological activity (Vollmanová et al., 2018)

The objective of thisstudy was to observe the new Slovak black oat varieties (Hucul and Norik), their nutritional composition, biological activity and technological properties - especially rheological.

\section{MATERIAL AND METHODS}

\section{Biological materials}

Two samples of the first Slovak black oats bred in the Research and Breeding Station Vígl'aš - Pstruša were thoroughly analyzed. These are specifically varieties named related from Slovak breeds of horses: Hucul (PS - 212) and Norik (PS - $\left.213 \mathrm{e}^{-}\right)$. Hucul -it excels in high one thousand grain weight (39.9 g) and bulk density (57 kg.hl-1). The length of the husk is short to medium, moderately radiant. Resistance to lodging is medium to good. The variety has no special requirements for agricultural technology. It is preferred in the nutrition of sport and racing horses for higher protein content and finer, less lignified husk. Year of registration: 2017.

Norik -it excels in high one thousand grain weight (40.6 g) and bulk density (56 $\mathrm{kg}^{\mathrm{h} \mathrm{h}^{-1}}$ ). The length of the husk is medium, slightly to moderately serrated. The resistance to lodging is medium to good. It has no special requirements for agricultural technology. It is preferred in the nutrition of sport and racing horses for higher protein content and finer, less lignified husk. Year of registration: 2017 (VURV, 2017).

The grain of the samples was homogenized using an Osttiroler Getreidemühlen laboratory mill (Green, Germany) and the wholemeal flour was used for analyzes. Wheat flour T-650 was purchase from mill Vitaflóra (Kolárovo, Slovak Republic).

To prepare the extract $0.5 \mathrm{~g}$ of the homogenized sample was extracted for $2 \mathrm{~h}$ in $40 \mathrm{ml}$ of $80 \%$ ethanol on a shaker (GFL 3005, Germany) at room temperature Subsequently, the extract was centrifuged (Rotofix 32A, Hettich, Germany; 4000 RPM, 10 minutes) and the supernatant was used for measurement (DPPH method, total polyphenol content).

An amount of $0.5 \mathrm{~g}$ of sample was homogenized in the mortar with sea sand, and repeatedly extracted with $10 \mathrm{~mL}$ acetone until the sample became colorless. The extract was filtered using a Whatman filter paper and used for detection of total carotenoid content.

An amount of $1 \mathrm{~g}$ of sample was extracted with $40 \mathrm{ml}$ of acidified ethanol (96\% ethanol acidified with $0.1 \mathrm{M} \mathrm{HCl}$ ) until the sample became colorless. The extract was filtered using a Whatman filter paper and used for detection of total anthocyanin content.

\section{Chemicals}

All chemicals used were of analytical grade and were purchased from SigmaAldrich (USA) and CentralChem (Slovakia).

\section{Nutritional evaluation}

Moisture content, protein, starch and ash content were determined following the standard AACC method 08-01 (AACC 1996). Nitrogen content was measured by the semi-micro Kjeldahl method, in which protein was calculated by using a factor of 6.25. Fat content was detected with Ancom XT15 Fat Extractor (USA) in line with producer instructions. The Streamlined $\beta$-glucan method (Megazyme method) has been successfully evaluated by AACC (Method 32-23.01) and ICC (Method no. 166, approved 1998). This method determines quantitative $(1,3),(1,4)-\beta$-D-glucan $(\beta$-D-glucan, mixed-linkage $\beta$-D-glucan) and is applicable to cereal grains (e.g. barley, oat, rye), their milling products and cereal based foods containing high level of glucose, after preextraction with aqueous ethanol. The method is a rapid procedure for direct, quantitative measurement of $(1,3),(1,4)-\beta$-D-glucan $(\beta$-D-using highly purified lichenase and $\beta$-glucosidase) $\beta$-D-Glucan is specifically hydrolysed by lichenase to oligosaccharides, which are then quantitatively cleaved to glucose by $\beta$-glucosidase. Glucose is measured using glucose oxidase-peroxidase-buffer mixture (Cauvain and Young, 2009). The absorbance is measured at $510 \mathrm{~nm}$.

The amount of mineral elements was analyzed by the ICP-OES method (ICPOES spectrophotometer, Thermo iCAP Dual 6500, USA) - the samples $(0.2 \mathrm{~g})$ were subjected to mineralization under high pressure, in $\mathrm{HNO}_{3} 65 \%$, super pure. All nutritional measurements were repeated six times.

\section{Biological evaluation}

\section{Antioxidant activity - DPPH method}

Antioxidant activity of samples was measured using 2,2-difenyl-1-picrylhydrazyl (DPPH) according to the procedures described by Sanchéz-Moréno, Larrauri and Saura-Calixto, 1998. All measurements were repeated six times.

\section{Total polyphenol content}

Total polyphenol content was measured in accordance to Singleton and Rossi, (1965) using Folin-Ciocalteu reagent. All measurements were repeated six times.

\section{Determination of total carotenoid content}

Total carotenoid content was determined according to STN 56 0053: 1986 at the wavelength of the absorption maximum for the dominant carotenoid which was $\beta$-carotene. All measurements were repeated six times.

\section{Determination of total anthocyanin content}

For determination ot total anthocyanin content extract of sample was measured at the wavelength of the absorption maximum for the dominant anthocyanin, which 
was cyanidine-3-glucoside (Fuleki and Francis, 1968). All measurements were repeated six times.

\section{Technological/rheological evaluation}

Technological/rheological measurements were made of prepared mixture of wholemeal oat flour of each variety in amount 3,6 and 9\% with wheat flour (T $650)$. Control (100\% T650 wheat flour) without addition of oat flour was also analysed.

For farinographic characteristic was used Farinograph-E (Brabender OhG, Duisburg, Germany) (ICC - Standard 115/1, 1992; AACC Method 54-21, 1995). Based on this measurement, following characteristics were determined: water absorption [\%], development time [min], degree of softening [FU], stability [min] and farinographic quality number [dimensionless]. For extensographic characteristic was used Extensograph-E (Brabender OhG, Duisburg, Germany) (ICC - Standard 114/1, 1992; AACC Method 54-10, 1995). Based on this measurement, following characteristics were determined: extensographic energy $\left[\mathrm{cm}^{2}\right]$, extensibility $[\mathrm{mm}]$ and resistance to extension [EU were determined. For amylographic characteristic was used Amylographe-E (Brabender OhG, Duisburg, Germany) (ICC - Standard 126/1; AACC Method 22-10, 1995). Based on this measurement, following characteristics were determined: the maximum gelatinization temperature $\left[{ }^{\circ} \mathrm{C}\right]$ and amylographic maximum $[\mathrm{AU}]$ was determined. All technological measurements were repeated six times.

\section{Statistical analysis}

All experiments were carried out six times and the mean of replications with standard deviations were reported. The experimental data were subjected to analysis of variance (ANOVA), using Duncan's test to determine significances between experimental groups at the significance level of 0.05 (Software XLSTAT, Addinsoft, France, 2020).

\section{RESULTS AND DISCUSSION}

\section{Results of nutritional evaluation}

Dry matter content in observed black oats was in amount $\sim 91.60 \%$ (Table 1). Determination of the dry matter and moisture content in cereals and related food is of great importance in order to ensure a proper technological quality and hygienic compliance related to durability due to a long shelf-life of cerelas. Biel, Jacyno and Kawęcka (2014) observed husked, dehusked and naked oats and indicated that the dry matter was highest in the husked oats $-90.25 \%$. By removing husks from the same varieties, the dry matter was reduced by almost $0.5 \%$. The average dry matter in naked oats was lower $-89.34 \%$. Their dry matter values are slightly lower compared to our husked black oats.

Starch content (Table 1) was higher in Norik variety - $44.85 \%$. Generally, saccharides in oat grain complex consist of starch, hemicellulose, cellulose, lignin and monosaccharides. The starch fraction is the predominant component in oat grains. Similar results also published Kriger et al. (2018) which determined starch content in common oat varieties and values ranged from 36.37 to $43.64 \%$, what is comparable to our results. However, our measured values are slightly lower with compared to research of Chapell $\boldsymbol{e t}$ al. (2017), which reported starch content in oat from 49.32 to $57.34 \%$. Van den Broeck et al. (2016) compared ten varieties of oats grown in sandy and loamy soils with the finding that oats grown in sandy soil had more starch $(58 \%)$ than that grown in clayey soil $(48.1 \%)$ Agro-ecological condition can have strong effect to nutritional and biological properties of plants.

Oat is a rich source of beta-glucans ( $\beta$-D-glucans) with bioactive and healing effects, e.g. immunostimulatory (activating immune cells macrophages), antiinflammatory, antimicrobial, antifibrotic, antidiabetic, hepatoprotective, or lowering blood glucose and cholesterol levels (Vollmanová et al., 2018). Prugar et al. (2008) reported that naked oat varieties contain the highest value of $\beta$ glucans from all cereals, ranging from 3.1 to $5.8 \%$. This is well comparable to our samples (Table 1); significantly higher $(\mathrm{P} \leq 0.05) \beta$-glucans content was found in Norik variety $-4.29 \%$, while in $\mathrm{Hucul}$ it was $3.15 \%$. Similar amount of $\beta$ glucans was described by several authors which reported amount $\sim 3.20 \%$ (Chapell et al, 2017), $\sim 3.30 \%$ (Kriger et al. 2018). Biel, Jacyno and Kawęcka (2014) determined that $\beta$-glucans is lower in husked varieties $-3.12 \%$, compared to dehusked $-4.48 \%$ and naked $-4.42 \%$ oats. Oat $\beta$-glucans have an important role in hypertension, dyslipidemia, insulin resistance and obesity. The basis for their health effects is their ability of intestinal bacteria to ferment them, making them more accessible to human body. They stimulate the defence system by supporting cellular immunity, thereby providing support against infections. Their anticytotoxic, antitumor and antimutagenic effects have also been demonstrated (Jamil et al., 2016).

The quantitative content of proteins and amino acids in oat grain is high and exceeds the content of other cereals (third place after wheat and winter rye) (Kriger et al., 2018). The protein content of oat grain is usually in the range of $11-15 \%$, but the advantage is high biological value as well as good digestibility
(Särkijärvi and Saastamoinen, 2006). However, we found lower crude protein content, with significantly higher $(\mathrm{P} \leq 0.05)$ amount in $\mathrm{Hucul}$ variety $-10.94 \%$ (Table 1). Also Biel, Bobko and Maciorowski (2009) found higher protein content in husked oat of variety Bohun $-11.44 \%$ and even more in naked oat of variety Polar $-12.75 \%$. Similar protein content in husked varieties was described by Sterna, Zute and Brunava (2016) - $10.58 \%$ what was markedly lower compared to naked varietes $-15.71 \%$ Proteins are not evenly distributed in the grain; about half of them is in endosperm and half in the aleurone layer. Nitrogenous substances in the examined oat grains ranged from 12.2 to $14.7 \%$, of which up to $87-90 \%$ are protein fractions and the others are non-protein nitrogenous substances. Protein fractions were in the samples examined represented as follows: glutelins 27.98 - $41.88 \%$, globulins $26.22-32 \%$, albumins 10.16 - $23.37 \%$ and prolamins $10.63-23.37 \%$ (Kriger et al., 2018) Avenins are oat stock proteins, prolamins, which contain from 10 to $13 \%$ of the total protein content, while the main stock proteins in oats are globulins, which make up approximately 55\%. Proteins in oats are generally higher lysine content and lower content of glutelins and prolamins compared to other cereals, therefore oat proteins suitably complement human amino acid requirements (Lásztity, 1998). Avenin content was higher in the examined oat varieties described by Van den Broeck et al. (2015), when they grew in clay soil compared to sandy soil and correlated with the total protein content. Prolamins of oats may contribute to the technological properties in relation to the quality of baking. Also they describe the absence of epitopes that stimulate celiac disease in contrast to prolamins from wheat, rye and barley. The husks also affect the crude protein content. According to Biel, Jacyno and Kawęcka (2014) observed husked varieties contain on average only $10.49 \%$, what is comparable to our black oats. Naked varieties contain on average $12.67 \%$ of crude protein. However, naked oats have higher values of all essential amino acids by $11.6 \%$ compared to husked and by $11.8 \%$ compared to dehusked varieties.

Fat content (Table 1) in observed wholemeal oat flours was significantly higher $(\mathrm{P} \leq 0.05)$ in variety Norik $-5.8 \%$. Comparable values were measured in selected varieties of black oats in research work of Ciolek et al. (2007) - from 4 to $4.94 \%$. They also reported that in the oat grain the unsaturated fatty acids make up to $80 \%$, which makes oats the most valuable cereal in terms of lipid content and composition. Hu et al. (2014) compared samples of oat flakes, which are commonly made from whole grains and are the most popular oat products. Lipid concentration in oat flakes samples from all over the world varied from 4.15 to $7.68 \%$. Compared to our black oats, similar lipid concentration in husked oats was described by Sterna, Zute and Brunava (2016) $-5.15 \%$. Unlike our black varieties of oats, yellow varieties observed by Chapell et al. (2017) contained a slightly higher content of lipids; with average value in the examined samples of $6.80 \%$. Biel, Jacyno and Kawecka (2014) published that the husks affect the ratio of individual fatty acids in oat - husked varieties contained more saturated fatty acids while compared to naked oat naked varieties.

Ash positively affects not only the colour but also the enzymatic activity of the flours. In addition, their content is related to the flours type number. The ash content (Table 1) was $2.48 \%$ in the $\mathrm{Hucul}$ variety what was significantly lower $(\mathrm{P} \leq 0.05)$ compared to Norik variety $(2.64 \%)$. Comparing the mineral composition (Table 2) of observed black oats, we can state, that Norik variety significantly exceeded $(\mathrm{P} \leq 0.05)$ in most minerals content: $\mathrm{Al}-0.41, \mathrm{Cr}-0.27, \mathrm{Fe}-5.94, \mathrm{~K}-$ 397.56, Mo $-0.05, \mathrm{Na}-6.33$ and $\mathrm{P}-365.81 \mathrm{mg} .100 \mathrm{~g}^{-1}$ compared to Hucul variety: $\mathrm{S}-142.89$ and $\mathrm{Zn}-2.05 \mathrm{mg} .100 \mathrm{~g}^{-1}$. The content of other microelements was not significantly different. Black oats differ substantially from other standard oat species in their high ash content. For example, Gambuś, Gambuś and Pisulewska (2006) reported the ash content in yellow of $3.35 \%$ and black oats up to $3.66 \%$. The ash content of black oats (2.16 to $2.53 \%$ ) measured by Ciolek $\boldsymbol{e t}$ al. (2007) are comparable with our results. Biel, Jacyno and Kawęcka (2014) pointed to differences between husked, dehusked and naked oat varieties with the following average ash values: husked $2.11 \%$; dehusked $1.98 \%$ and naked only $1.82 \%$. This finding confirmed, that most of the mineral compounds are concentrated in the bran layers. Ciolek et al. (2007) and Chapell, et al. (2017) reported the following values of individual minerals $\left(\mathrm{mg} .100 \mathrm{~g}^{-1}\right.$ ): $\mathrm{Na}$ was not determined by the first authors, while the others measured $12.60 ; \mathrm{K}-362.60$, others 408.20; $\mathrm{Ca}-13.50$, others $54.90 ; \mathrm{Mg}-101.40$, others $109.30 ; \mathrm{P}-$ 351.00 others $371.70 ; \mathrm{Mn}-4.19$ others $4.06 ; \mathrm{Fe}-3.96$ others $3.95 ; \mathrm{Cu}-0.20$ others 3.45 and $\mathrm{Zn}-3.05$ others 2.73. To compare with black oats, Yossef $\boldsymbol{e t} \boldsymbol{a l}$. (2016) compared minerals content of red and common oats as follow: $\mathrm{P}-496.61$ and 472.57, $\mathrm{K}-362$ and $350, \mathrm{Na}-7.03$ and 5.35, $\mathrm{Mg}-112.25$ and $120.67, \mathrm{Ca}-$ 71.71 and $54.70, \mathrm{Zn}-3.62$ and $3.44, \mathrm{Cu}-1.20$ and $1.33, \mathrm{Mn}-3.66$ and $4.62, \mathrm{Fe}$ -24.21 and $13.76 \mathrm{mg} .100 \mathrm{~g}^{-1}$. 
Table 1 Nutritional parameters [\%] of analysed black oats

\begin{tabular}{lcc} 
Parameter & Hucul & Norik \\
\hline Dry matter content & $91.68 \pm 0.11^{\mathrm{a}}$ & $91.55 \pm 0.07^{\mathrm{a}}$ \\
Starch content & $42.34 \pm 0.47^{\mathrm{b}}$ & $44.85 \pm 0.22^{\mathrm{a}}$ \\
Crude protein content & $10.94 \pm 0.19^{\mathrm{a}}$ & $10.31 \pm 0.13^{\mathrm{b}}$ \\
Fat content & $3.58 \pm 0.24^{\mathrm{b}}$ & $5.80 \pm 0.23^{\mathrm{a}}$ \\
$\boldsymbol{\beta}$-glucan content & $3.15 \pm 0.13^{\mathrm{b}}$ & $4.29 \pm 0.14^{\mathrm{a}}$ \\
Ash content & $2.48 \pm 0.05^{\mathrm{b}}$ & $2.64 \pm 0.06^{\mathrm{a}}$
\end{tabular}

$\overline{\text { mean }} \pm$ S.D; different letters in column denote mean values that statistically differ one from another

Table 2 Mineral composition of analysed black oats [mg.100 g $\left.{ }^{-1}\right]$

\begin{tabular}{lll}
\hline $\begin{array}{l}\text { Mineral } \\
\text { compound }\end{array}$ & Hucul & Norik \\
\hline Al & $0.07 \pm 0.08^{\mathrm{b}}$ & $0.41 \pm 0.09^{\mathrm{a}}$ \\
$\mathbf{C a}$ & $79.38 \pm 1.54^{\mathrm{a}}$ & $75.59 \pm 2.50^{\mathrm{b}}$ \\
$\mathbf{C d}$ & $0.01 \pm 0.00$ & $0.01 \pm 0.00$ \\
$\mathbf{C r}$ & $0.11 \pm 0.04^{\mathrm{b}}$ & $0.27 \pm 0.01^{\mathrm{a}}$ \\
$\mathbf{C u}$ & $0.35 \pm 0.06^{\mathrm{a}}$ & $0.41 \pm 0.01^{\mathrm{a}}$ \\
$\mathbf{F e}$ & $\mathrm{n} . \mathrm{d}$. & $5.94 \pm 0.52^{\mathrm{a}}$ \\
$\mathbf{K}$ & $335.64 \pm 1.01^{\mathrm{b}}$ & $397.56 \pm 5.57^{\mathrm{a}}$ \\
$\mathbf{M g}$ & $159.26 \pm 1.75^{\mathrm{a}}$ & $147.30 \pm 2.06^{\mathrm{b}}$ \\
$\mathbf{M n}$ & $4.40 \pm 0.04^{\mathrm{a}}$ & $4.32 \pm 0.04^{\mathrm{a}}$ \\
$\mathbf{M o}$ & $0.01 \pm 0.00^{\mathrm{b}}$ & $0.05 \pm 0.00^{\mathrm{a}}$ \\
$\mathbf{N a}$ & $4.23 \pm 0.05^{\mathrm{b}}$ & $6.323 \pm 0.28^{\mathrm{a}}$ \\
$\mathbf{P}$ & $355.64 \pm 1.75^{\mathrm{b}}$ & $365.81 \pm 1.88^{\mathrm{a}}$ \\
$\mathbf{P b}$ & $0.02 \pm 0.02^{\mathrm{a}}$ & $0.01 \pm 0.01^{\mathrm{a}}$ \\
$\mathbf{S}$ & $142.90 \pm 0.58^{\mathrm{a}}$ & $134.03 \pm 1.04^{\mathrm{b}}$ \\
$\mathbf{S e}$ & $0.05 \pm 0.05^{\mathrm{a}}$ & $n . d$. \\
$\mathbf{S r}$ & $0.36 \pm 0.00^{\mathrm{a}}$ & $0.35 \pm 0.01^{\mathrm{a}}$ \\
$\mathbf{Z n}$ & $2.05 \pm 0.00^{\mathrm{a}}$ & $1.92 \pm 0.02^{\mathrm{b}}$ \\
\hline
\end{tabular}

mean \pm S.D; different letters in column denote mean values that statistically differ one from another; n.d. - not detected

Table 3 Biological activity of selected black oats

\begin{tabular}{|c|c|c|}
\hline Parameter & Hucul & Norik \\
\hline $\begin{array}{l}\text { Antioxidant activity } \\
{\left[\mathrm{mg} \mathrm{TEAC}^{-1} \mathrm{~g}^{-1}\right]}\end{array}$ & $2.97 \pm 0.05^{\mathrm{a}}$ & $3.03 \pm 0.06^{\mathrm{a}}$ \\
\hline $\begin{array}{l}\text { Total polyphenols } \\
{\left[\text { mg GAE.g }{ }^{-1}\right]}\end{array}$ & $0.19 \pm 0.04^{b}$ & $0.15 \pm 0.04^{\mathrm{a}}$ \\
\hline $\begin{array}{l}\text { Total carotenoids } \\
{\left[\mu \mathrm{g} . \mathrm{g}^{-1}\right]}\end{array}$ & $5.91 \pm 0.13^{\mathrm{b}}$ & $7.47 \pm 0.09^{\mathrm{a}}$ \\
\hline $\begin{array}{l}\text { Total anthocyanins } \\
{\left[\mu{\left.\mathrm{g} . \mathrm{g}^{-1}\right]}\right.}\end{array}$ & $22.00 \pm 3.00^{\mathrm{a}}$ & $14.67 \pm 3.06^{\mathrm{b}}$ \\
\hline
\end{tabular}

mean \pm S.D; different letters in column denote mean values that statistically differ one from another; TEAC - Trolox equivalent antioxidant activity; GAE - gallic acid equivalent

\section{Biological activity}

The values of the total antioxidant activity in the flours from our examined oat varieties were almost the same (Table 3), ranging around $\sim 3 \mathrm{mg}$ TEAC.g ${ }^{-1}$. Slightly lower values were also measured in the research by Chmelová et al. (2015), when the highest total antioxidant activity determined by methanol extraction was in the black-husked variety Paddock - $2.81 \mathrm{mg}$ TEAC. ${ }^{-1}$ According to them oats are used as a healthy food due to their significant content of antioxidants - large number of phenolic compounds (ferulic, coffee, $p$ hydroxybenzoic, $p$-hydroxyphenylacetic, vanillic, protocatechuic, $p$-coumaric or sinapic acid), tocols, phytic acid, flavonoids, sterols, avenanthramides and $\beta$ glucans. (Varga et al. (2018) compared the content of total soluble and tightly bound antioxidants in the husks (where antioxidants are in the highest concentrations) of yellow, red and black oat varieties. Black varieties had much higher antioxidant activity, they contained $57.6 \%$ and $61.9 \%$ more total soluble antioxidants than yellow, resp. red varieties, and 135.5 resp. $38.9 \%$ more tightly bound antioxidants compared to yellow, resp. red varieties. Also Brindzová et al (2008) confirmed the highest total antioxidant activity in black oats varieties in comparison with yellow and naked varieties.

Total polyphenols content (Table 3) was higher in Hucul variety. According to Chen et al. (2018), polyphenols are bioactive secondary metabolites present in fruits, vegetables and cereals. In food, these metabolites can contribute not only to antioxidant activity, but also to colour or taste. Consumption of some cereal products protects human body against the development of chronic diseases such as diabetes, cancer and cardiovascular disease. As antioxidants, phenolic compounds prevent oxidative damage to cellular organelles, proteins, lipids,

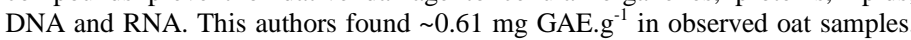
Higher amount of total polyphenols in oat samples was measured by Walters $\boldsymbol{e}$ al. (2018) which found value ranged from 0.31 to $0.89{\mathrm{mg} \mathrm{GAE} . \mathrm{g}^{-1} \text { and Hitayezu }}^{-1}$ et al. (2015) which determined values $0.61-0.98 \mathrm{mg}$ of GAE. $\mathrm{g}^{-1}$. Among the important biologically active phenolic substances of oats, the determination of which, however, is not the aim of this work, are avenanthramides. It was reported that they have various bioactive properties, such as antioxidant, antiinflammatory and antiproliferative effects. In addition, they can also regulate cellular responses during inflammation through their interactions with molecular and signalling pathways. Moreover, these compounds can inhibit the growth of four different human colon cancer-causing cells (Wang et al., 2015). They are not to be found in any other cereals. Hitayezu, et al. (2015) and Walters et al. (2018) found that enrichment of food with oat bran can substantially increase the amount of these substances.

Based on the concentration of natural colorants (anthocyanins, carotenoids), the colors of individual grain parts (endosperm, aleurone layer, pericarp, husks) range from white through yellow, gray, red to black (Chmelová et al., 2015). We confirmed that while Norik variety contained significantly higher $(\mathrm{P} \leq 0.05)$ amount of carotenoids $\left(7.47 \mu \mathrm{g} \cdot \mathrm{g}^{-1}\right)$, Hucul variety had significantly more $(\mathrm{P} \leq 0.05)$ anthocyans $\left(22 \mu \mathrm{g} \cdot \mathrm{g}^{-1}\right)$. Carotenoids play an important role in the human body, for example, $\alpha$ - and $\beta$-carotene have a primary function in vitamin A biosynthesis, important for proper visual function, embryo and fetal development. Lutein and zeaxanthin, in turn, play an important role in promoting eye and skin health as well as in reducing the incidence of cancer and cardiovascular disease (Hussain et al., 2015). Anthocyanins are attributed positive antioxidant, anticancer effects, protect the retina, retard aging and have a positive effect on intestinal health.

\section{Technological/rheological properties}

In the control sample (wheat flour $\mathrm{T}$ 650) it was recorded the highes amylographic maximum - 1593 AU (Table 4). With the addition of whole-grain oatmeal flour in the selected percentages, the amylographic maximum decreased; most notably in variant $9 \%$ addition of whole-grain oatmeal flour variety $\mathrm{Hucul}$ 1404 AU. From results it can be concluded that the Hucul variety had better amylolytic activity with compare to Norik variety. This finding indicated that observed variety is richer for $\alpha$-amylase, which is important in bakery industry, because amylolytic activity very strongly influenced character of bread crumb (porosity, flexibility, taste). Maximum gelatinization temperature was not affected, and ranging around $\sim 92.09{ }^{\circ} \mathrm{C}$ value (Table 4). For comparison, Hüttner et al., (2010) examined pure oat flours from different countries. The amylographic maximum in such flours ranged from 328.20 to $402.14 \mathrm{AU}$ and the temperature in the gelatinisation maximum from 82.37 to $83.57{ }^{\circ} \mathrm{C}$. These data also correlated with our research, because the obtained indicators decreased after the addition of whole-grain oatmeal flour. Shah et al. (2016) observed new Himalayan varieties of oat. In their study amylographic maximum was higher, and ranged from 460.33 to $489.33 \mathrm{AU}$, and the gelatinisation maximum temperatures was also higher with the value $\sim 95^{\circ} \mathrm{C}$.

Table 4 Amylographic characteristic of flour mixture enriched with black oats

\begin{tabular}{lcc}
\hline Sample & $\begin{array}{c}\text { Amylographic } \\
\text { maximum } \\
\text { [AU] }\end{array}$ & $\mathbf{T}_{\max }\left[{ }^{\circ} \mathbf{C}\right]$ \\
\hline Control (wheat flour & $1594.00 \pm 6.56^{\mathrm{a}}$ & $91.20 \pm 1.06^{\mathrm{c}}$ \\
T650) & $1487.67 \pm 18.93^{\mathrm{b}}$ & $92.17 \pm 0.76^{\mathrm{b}}$ \\
Control + Hucul 3\% & $1568.33 \pm 16.50^{\mathrm{a}}$ & $92.03 \pm 1.10^{\mathrm{b}}$ \\
Control + Hucul 6\% & $1404.00 \pm 6.51^{\mathrm{c}}$ & $91.37 \pm 1.29^{\mathrm{c}}$ \\
Control + Hucul 9\% & $1572.67 \pm 21.79^{\mathrm{a}}$ & $92.77 \pm 0.64^{\mathrm{a}}$ \\
Control + Norik 3\% & $1524.67 \pm 13.05^{\mathrm{ab}}$ & $92.73 \pm 1.14^{\mathrm{a}}$ \\
Control + Norik 6\% $_{\text {Control + Norik 9\% }}$ & $1515.67 \pm 13.87^{\mathrm{ab}}$ & $92.33 \pm 0.60^{\mathrm{b}}$ \\
\hline
\end{tabular}

mean \pm S.D; different letters in column denote mean values that statistically differ one from another; $\mathrm{AU}$ - amylographic unit; $\mathrm{T}_{\max }-$ maximum gelatinization temperature

It was found the significantly highest farinographic water absorption (Table 5) in flour mixture after addition of $9 \% \mathrm{Hucul}$ variety whole-grain flour $-59.97 \%$ especially compared with to control sample. It was no surprise that the significantly lowest development time (Table 5) was determined in control wheat flour ( $\mathrm{T}$ 650) $-2.33 \mathrm{~min}$. and increase with black oats whole-grain flour addition to maximum ( $8.27 \mathrm{~min}$.) in variant $6 \%$ of variety Norik. As expected, addition of black oats whole-grain flour reduced dough stability of most enriched flour mixtures. However the addition of $3 \%$ whole-grain flour variety Norik exceeded even control flour $(11.97 \mathrm{~min}$.) with dough stability of $14.63 \mathrm{~min}$. The highest level of degree of softening (Table 5) was found in variant with addition of $6 \%$ Hucul whole-grain flour - 61 FU with compared to lowest in control sample 38.33 FU. In our study was determined different farinographic quality number (Table 5) ranged from 104.67 (control sample) to 186.67 (variant with 3\% Norik whole-grain flour). Rieder et al. (2012) investigated how the addition of barley flour and oat bran to wheat bread affects the overall water absrobtion. Replacing wheat with $40 \%$ of oats or barley significantly increased water absorption by $8-$ $11.8 \%$ with compared to pure wheat flour. This is probably due to the high fibre content in oat and barley flour. Interestingly, oat bran showed significantly higher water absorption than barley, although the total amount of fibre was lower. They also found that the content and molecular weight of $\beta$-glucans was more 
important for water absorption than other types of fibre, because oat had much higher $\beta$-glucan content than barley. Their findings are comparable to our results; we supposed that mainly $\beta$-glucans and also other non-starch polysaccharides can positively influenced the farinographic characteristic of dough.

Table 5 Farinographic characteristic of flour mixture enriched with black oats

\begin{tabular}{|c|c|c|c|c|c|}
\hline Sample & $\begin{array}{l}\text { Water } \\
\text { absorption } \\
{[\%]}\end{array}$ & $\begin{array}{l}\text { Development } \\
\text { time } \\
{[\mathrm{min}]}\end{array}$ & $\begin{array}{l}\text { Stability } \\
\text { [min] }\end{array}$ & $\begin{array}{l}\text { Degree of } \\
\text { softening } \\
{[\mathrm{FU}]}\end{array}$ & $\begin{array}{l}\text { Farinographic } \\
\text { quality } \\
\text { number } \\
\text { [dimensionless] }\end{array}$ \\
\hline $\begin{array}{l}\text { Control (wheat flour } \\
\text { T650) }\end{array}$ & $58.57 \pm 0.50^{\mathrm{cd}}$ & $2.33 \pm 0.15^{\mathrm{f}}$ & $11.97 \pm 0.31^{\mathrm{b}}$ & $38.33 \pm 3.06^{\mathrm{de}}$ & $104.67 \pm 6.11^{\mathrm{c}}$ \\
\hline Control + Hucul 3\% & $59.00 \pm 0.44^{\text {bcd }}$ & $6.57 \pm 0.15^{\mathrm{e}}$ & $11.03 \pm 0.25^{\mathrm{c}}$ & $45.33 \pm 4.51^{\mathrm{cd}}$ & $125.00 \pm 5.00^{\mathrm{b}}$ \\
\hline Control + Hucul $6 \%$ & $59.30 \pm 0.36^{\mathrm{b}}$ & $7.67 \pm 0.25^{\mathrm{b}}$ & $9.13 \pm 0.42^{\mathrm{e}}$ & $61.00 \pm 5.29^{\mathrm{a}}$ & $108.00 \pm 3.00^{c}$ \\
\hline Control + Hucul 9\% & $59.97 \pm 0.15^{\mathrm{a}}$ & $6.80 \pm 0.27^{\mathrm{de}}$ & $8.40 \pm 0.50^{\mathrm{e}}$ & $50.00 \pm 4.58^{\mathrm{bc}}$ & $118.33 \pm 4.51^{\mathrm{b}}$ \\
\hline Control + Norik 3\% & $58.40 \pm 0.27^{\mathrm{d}}$ & $7.07 \pm 0.31^{\mathrm{cd}}$ & $14.63 \pm 0.50^{\mathrm{a}}$ & $31.67 \pm 3.79^{\mathrm{e}}$ & $186.67 \pm 7.64^{\mathrm{a}}$ \\
\hline Control + Norik $6 \%$ & $59.17 \pm 0.31^{\mathrm{bc}}$ & $8.27 \pm 0.15^{\mathrm{a}}$ & $10.07 \pm 0.35^{\mathrm{d}}$ & $44.00 \pm 5.00^{\mathrm{cd}}$ & $124.00 \pm 6.00^{\mathrm{b}}$ \\
\hline Control + Norik $9 \%$ & $59.67 \pm 0.38^{\mathrm{ab}}$ & $7.33 \pm 0.15^{\text {bc }}$ & $8.40 \pm 0.44^{\mathrm{e}}$ & $55.67 \pm 4.51^{\mathrm{ab}}$ & $121.67 \pm 4.04^{\mathrm{b}}$ \\
\hline
\end{tabular}

mean \pm S.D; different letters in column denote mean values that statistically differ one from another;

FU - farinographic unit; min - minute

The control sample had an average resistance to extension of $259.33 \mathrm{EU}$ (Table 6) while the lowest resistance was observed in variant with addition of 6 and $9 \%$ Hucul variety whole-grain flour (224.67 and 222.33 EU, respectively). All observed flours reached the high extensibility values characteristic of "weak" flours ranged from 184 to $205 \mathrm{~mm}$ (Table 6). Extensographic energy is the factor that was the most affected with the addition of whole-grain oat flour. While in the control flour and flour mixtures (Hucul $3 \%$ and Norik 3\%) it was still in the value around $\sim 100 \mathrm{~cm}^{2}$, the addition of 6 and $9 \%$ caused its significant decrease to values below $90 \mathrm{~cm}^{2}$. Londono et al. (2015a) used pure oatmeal flour and with the addition of gluten as a base and addition of medium and highly viscous $\beta$ glucan. They found that gluten-enriched dough was more extensible $-61 \mathrm{~mm}$, while its equivalent without gluten addition was only $15 \mathrm{~mm}$. The addition of
$3.8 \%$ of $\beta$-glucan significantly reduced the extensibility of gluten-added samples, namely by $22.8 \mathrm{~mm}$ for medium viscosity up to $34.9 \mathrm{~mm}$ for high-viscous $\beta$ glucan. For samples that did not contain gluten, the decrease extensibility was not so significant. Londono et al. (2015b) discussed in other research the effect of roasting and grinding (particle size) on dough extensibility. The untreated oatmeal dough (control) and steam-dried dough gave low stretching resistance and their extensibility was about $85 \mathrm{~mm}$, while in infrared drying dough was short with high resistance. The size of the particles and the addition of bran also played an important role; fine oatmeal with the addition of fine bran $(<0.25 \mathrm{~mm})$ gave a tough dough with low resistance, while coarser fractions with the addition of coarser bran gave a rather short dough with higher resistance.

Table 6 Extensographic characteristic of flour mixture enriched with black oats

\begin{tabular}{llll}
\hline Sample & $\begin{array}{l}\text { Resistance } \\
\text { extension } \\
{[\text { EU] }}\end{array}$ & $\begin{array}{c}\text { to } \\
\text { Extensibility } \\
{[\mathbf{m m}]}\end{array}$ & $\begin{array}{l}\text { Extensographic energy } \\
\left.\text { [cm }^{2}\right]\end{array}$ \\
\hline Control (wheat flour T650) & $259.33 \pm 11.93^{\mathrm{a}}$ & $189.67 \pm 5.51^{\mathrm{a}}$ & $105.67 \pm 5.03^{\mathrm{a}}$ \\
Control + Hucul 3\% & $244.67 \pm 9.45^{\mathrm{ab}}$ & $195.00 \pm 7.81^{\mathrm{a}}$ & $96.67 \pm 4.04^{\mathrm{b}}$ \\
Control + Hucul 6\% & $224.67 \pm 11.72^{\mathrm{bc}}$ & $199.33 \pm 5.51^{\mathrm{a}}$ & $85.33 \pm 2.08^{\mathrm{cd}}$ \\
Control + Hucul 9\% & $222.33 \pm 15.04^{\mathrm{c}}$ & $190.67 \pm 4.73^{\mathrm{a}}$ & $77.00 \pm 3.46^{\mathrm{e}}$ \\
Control + Norik 3\% & $255.67 \pm 10.41^{\mathrm{a}}$ & $193.00 \pm 2.65^{\mathrm{a}}$ & $100.00 \pm 2.00^{\mathrm{ab}}$ \\
Control + Norik 6\% & $252.33 \pm 7.23^{\mathrm{a}}$ & $190.00 \pm 2.00^{\mathrm{a}}$ & $89.00 \pm 2.65^{\mathrm{c}}$ \\
Control + Norik 9\% & $240.33 \pm 10.97^{\mathrm{abc}}$ & $190.00 \pm 4.36^{\mathrm{a}}$ & $80.67 \pm 6.11^{\mathrm{de}}$ \\
\hline
\end{tabular}

mean \pm S.D; different letters in column denote mean values that statistically differ one from another;

EU - extensographic unit; $\mathrm{mm}$ - millimetre; $\mathrm{cm}^{2}$ - square centimetre

\section{CONCLUSION}

According to the obtained results, it can be concluded that selected varieties of black oats Hucul and Norik had a different nutritional composition. With almost the same content of dry matter, the Hucul variety contained significantly more crude protein. Norik, variety on the other hand, had more starch, fat and ash content. In Norik variety was also significantly higher content of several mineral compounds especially $\mathrm{Fe}, \mathrm{K}, \mathrm{Mo}, \mathrm{Na}$ and P.In Hucul variety was observed significantly higher content of $\mathrm{S}$ and $\mathrm{Zn}$. Biological activity of both varieties was similar; they differed mainly in the content of carotenoids and anthocyans. While Hucul contained significantly more anthocyanins, Norik contained more carotenoids. Based on amylograph results, wheat flour as control sample reached high values of an amylographic maximum of almost $1600 \mathrm{AU}$ and the addition of whole-grain oat flour was able to reduce this high value by almost up to $200 \mathrm{AU}$ with a $9 \%$ addition of the $\mathrm{Hucul}$ variety. Farinographic indicators were generally good for control flour and experimental flour mixtures. As important may be significant increase of water absorption which is very important parameters for bakery industry - higher water absorption=higher dough yield. The extenzograph results pointed to the higher extensibility of the dough at low resistance in experimental flour mixtures. Overall, we can concluded that observed new black oat varieties are nutritionally very interesting, especially due to the fat conten and the content of biologically active substances. Their addition into flour mixtures can improve some technological parameters, however we recommend further research and practical application.

Conflicts of interest: All authors declare no conflicts of interest.

Acknowledgments: This research was supported by the project 05-GASPU-2018 (50\%); by grant APVV-16-0289 (40\%) and also VEGA 1/0180/20 (10\%)

\section{REFERENCES}

AACC (1984) Approved methods of analysis. St. Paul, Minnesota: The American association of cereal chemists 280

AACC Methods (1996) 8TH, E.D., Methods 08-01, 44-05A, 46-13, 54-20. St Paul, Minnesota: The American association of cereal chemists. 200-210.

AACC-International, Approved methods of analysis, 11thed. method 3223.01. Beta-glucan content of barley and oats-rapid enzymatic procedure. AACC International, ST. Paul, MINNESOTA, USA. 2013.

Andersson, A. A. M., \& Börjesdotter, D. (2011). Effects of environment and variety on content and molecular weight of $\beta$-glucan in oats. Journal of Cereal Science, 54, 122-128. https://doi.org/10.1016/j.jcs.2011.03.003

Ballabio, C., Uberti, F., Manferdelli, S., Vacca, E., Boggini, G., Redaelli, R. \& Restani, P. (2011). Molecular characterisation of 36 oat varieties and in vitro assessment of their suitability for coeliacs' diet. Journal of Cereal Science, 54, 110-115. https://doi.org/10.1016/j.jcs.2011.04.004

Biel, W., Bobko, K., \& Maciorowski, R. (2009). Chemical composition and nutritive value of husked and naked oats grain. Journal of Cereal Science, 49 413-418. https://doi.org/10.1016/j.jcs.2009.01.009

Biel, W., Jacyno, E., \& Kawęcka, M. (2014). Chemical composition of hulled, dehulled and naked oat grains. South African Journal of Animal Science, 44, 189 https://doi.org/10.4314/sajas.v44i2.12

Boczkowska, M., Podyma, W., \& Łapiński, B. (2016). Oat. Genetic and Genomic Resources for Grain Cereals Improvement, 159-225. https://doi.org/10.1016/b978-0-12-802000-5.00004-6

Brindzová L., Čertík M., Rapta P., Zalibera M., Mikulajová A. \& Takácsová M. (2008): Antioxidant activity, $\beta$-glucan and lipid contents of oat varieties. Czech Jounal of Food Science, 26, 163-173.

Butt, M. S., Tahir-Nadeem, M., Khan, M. K. I., Shabir, R., \& Butt, M. S. (2008) Oat: unique among the cereals. European Journal of Nutrition, 47, 68-79. https://doi.org/10.1007/s00394-008-0698-7 
Cauvain, S. P. \& Young, L. S. (2009). The ICC Handbook of Cereals, Flour, Dou-gh \& Product Testing: Methods and Applications. Lancaster DEStech Publications. ISBN: 978-1-932078-99-2. https://doi.org/10.1111/j.1757837X.2010.00062.x

Chappell, A., Scott, K. P., Griffiths, I. A., Cowan, A. A., Hawes, C., Wishart, J., \& Martin, P. (2017). The agronomic performance and nutritional content of oat and barley varieties grown in a northern maritime environment depends on variety and growing conditions. Journal of Cereal Science, 74, 1-10. https://doi.org/10.1016/j.jcs.2017.01.005

Chen, C., Wang, L., Wang, R., Luo, X., Li, Y., Li, J., Li, Y. \& Chen, Z. (2018). Phenolic contents, cellular antioxidant activity and antiproliferative capacity of different varieties of oats. Food Chemistry, 239, 260-267. https://doi.org/j.foodchem.2017.06.104

Chmelová, D., Ondrejovič, M., Havrlentová, M., \& Hozlár, P. (2015) Antioxidant activity in naked and hulled oat (Avena sativa L.) varieties. Journal of Microbiology, Biotechnology and Food Sciences, 4, 63-65. https://doi.org/10.15414/jmbfs.2015.4.special3.63-65

Ciołek, A., Makarski, B., Makarska, E. \& Zadura, A. (2007). Content of some nutrients in new black oat strain. Journal of elementology 12, 251-259.

Clayton, W. D., Vorontsova, M., Harman, K. T. \& Williamson, H. (2014). Avena strigosa. In: Grass Base - The Online World Grass Flora. Kew Royal Botanic Gardens. http://www.kew.org/data/grassesdb/www/imp01116.htm (cited 09/2020).

FAO (2020a). Crop Prospects and Food Situation - Quarterly Global Report No. 1, March 2020. Rome. https://doi.org/10.4060/ca8032en

FAO (2020b). Food Outlook - Biannual Report on Global Food Markets: June 2020. Food Outlook, 1. Rome. https://doi.org/10.4060/ca9509en

FAOSTAT (2020). Agricultural data. Available from: http://www.fao.org/faostat/en/\#rankings/countries_by_commodity (cited 09/2020).

Frid, A., Tura, A., Pacini, G., \& Ridderstråle, M. (2017). Effect of Oral Pre-Meal Administration of Betaglucans on Glycaemic Control and Variability in Subjects with Type 1 Diabetes. Nutrients, 9, 1004. https://doi.org/10.3390/nu9091004

Fuleki, T., \& Francis, T.J. (1968). Quantitative methods for anthocyanins Journal of Food Science, 33, 78-83 https://doi.org/10.1111/j.13652621.1968.tb00887.x

Gambuś, H., Gambuś, F. \& Pisulewska, E. (2006). Całoziarnowa maka owsiana jako źródło składników dietetycznych w chlebach pszennych. Biuletyn instytutu hodowli i aklimatyzacji roślin, 239, 259-267.

Gracia, M.-B., Armstrong, P. R., Rongkui, H., \& Mark, S. (2017). Quantification of betaglucans, lipid and protein contents in whole oat groats (Avena sativa $\mathrm{L}$.) using near infrared reflectance spectroscopy. Journal of Near Infrared Spectroscopy, 25, 172-179. https://doi.org/10.1177/0967033517709615

Gupta, S., Cox, S., \& Abu-Ghannam, N. (2010). Process optimization for the development of a functional beverage based on lactic acid fermentation of oats. Biochemical Engineering Journal, 52, 199-204. https://doi.org/10.1016/j.bej.2010.08.008

Hitayezu, R., Baakdah, M. M., Kinnin, J., Henderson, K., \& Tsopmo, A. (2015). Antioxidant activity, avenanthramide and phenolic acid contents of oat milling fractions. Journal of Cereal Science, 63, 35-40. https://doi.org/10.1016/j.jcs.2015.02.005

Hu, X.-Z., Zheng, J.-M., Li, X., Xu, C., \& Zhao, Q. (2014). Chemica composition and sensory characteristics of oat flakes: A comparative study of naked oat flakes from China and hulled oat flakes from western countries. Journal of Cereal Science, 60, 297-301. https://doi.org/10.1016/j.jcs.2014.05.015 Hussain, A., Larsson, H., Kuktaite, R., Olsson, M., \& Johansson, E. (2015) Carotenoid Content in Organically Produced Wheat: Relevance for Human Nutritional Health on Consumption. International Journal of Environmental Research and Public Health, 12, 14068-14083. https://doi.org/10.3390/ijerph121114068

Hüttner, E. K., Bello, F. D., \& Arendt, E. K. (2010). Rheological properties and bread making performance of commercial wholegrain oat flours. Journal of Cereal Science, 52, 65-71. https://doi.org/10.1016/j.jcs.2010.03.004

ICC - Standard 114/1, 1992, AACC Method 54-10: 1995 Method for using the Brabender Extensograph

ICC - Standard 115/1, 1992, AACC Method 54-21: 1995 Method for using the Brabender Farinograph

ICC - Standard 126/1, AACC Method 22-10,1995: Method for using the Brabender Amylograph

ICC - International Association for Cereal Science and Technology (ICC) standard method no. 166. Determination of $\beta$-glucan in barley, oat and rye. ICC Secretariat, Vienna.1998.

Jamil, M., Latif, N., Mansoor, M., Awan, A. A., Khan, A., Eshan Elahi, E. M. \& Anwar, F. (2016). A Review on Multidimensional Aspects of Oat (Avena sativa) Crop and Its Nutritional, Medicinal and Daily Life Importance. World Applied Sciences Journal, 34

1269-1275. https://doi.org/10.5829/idosi.wasi.2016.1269.1275.

Jenkins, A., Jenkins, D., Zdravkovic, U., Würsch, P., \& Vuksan, V. (2002). Depression of the glycemic index by high levels of $\beta$-glucan fiber in two functional foods tested in type 2 diabetes. European Journal of Clinical Nutrition, 56, 622-628. https://doi.org/10.1038/sj.ejen.1601367

Kaukinen, K., Collin, P., Huhtala, H., \& Mäki, M. (2013). Long-term consumption of oats in adult celiac disease patients. Nutrients, 5, 4380-4389. https://doi.org/10.3390/nu5114380

Kilci, A., \& Gocmen, D. (2014). Phenolic acid composition, antioxidant activity and phenolic content of tarhana supplemented with oat flour. Food Chemistry, 151, 547-553. https://doi.org/10.1016/j.foodchem.2013.11.038

Klose, C., Schehl, B. D., \& Arendt, E. K. (2009). Fundamental study on protein changes taking place during malting of oats. Journal of Cereal Science, 49, 8391. https://doi.org/10.1016/j.jcs.2008.07.014

Kriger, O. V., Kashirskikh, E. V., Babich, O. O. \& Noskova, S. Y. (2018). Oat protein concentrate production. Foods and Raw Materials, 6, 47-55. https://doi.org/10.21603/2308-4057-2018-1-47-55

Lásztity, R. (1998). Oat grain - a wonderful reservoir of natural nutrients and biologically active substances. Food Reviews International, 14, 99-119. https://doi.org/10.1080/87559129809541150

Liu, Y., Zou, M., \& Wang, Q. (2011). Distortion identification technique based on Hilbert-Huang transform in video stabilization. Transactions of Tianjin University, 17, 68-74. https://doi.org/10.1007/s12209-011-1474-y

Londono, D. M., Gilissen, L. J. W. J., Visser, R. G. F., Smulders, M. J. M., \& Hamer, R. J. (2015a). Understanding the role of oat $\beta$-glucan in oat-based dough systems. Journal of Cereal Science, 62, 1-7. https://doi.org/10.1016/j.jcs.2014.12.003

Londono, D. M., Smulders, M. J. M., Visser, R. G. F., Gilissen, L. J. W. J., \& Hamer, R. J. (2015b). Effect of kilning and milling on the dough-making properties of oat flour. LWT - Food Science and Technology, 63, 960-965. https://doi.org/10.1016/j.lwt.2015.04.033

Marshall, A., Cowan, S., Edwards, S. et al. (2013). Crops that feed the world 9 Oats - a cereal crop for human and livestock feed with industrial applications. Food Security. 5, 13-33. https://doi.org/10.1007/s12571-012-0232-x

Önning, G., Wallmark, A., Persson, M., Åkesson, B., Elmståhl, S., \& Öste, R. (1999). Consumption of Oat Milk for 5 Weeks Lowers Serum Cholesterol and LDL Cholesterol in Free-Living Men with Moderate Hypercholesterolemia. Annals of Nutrition and Metabolism, 43(5), 301-309. https://doi.org/10.1159/000012798

Pridal, A. A., Böttger, W., \& Ross, A. B. (2018). Analysis of avenanthramides in oat products and estimation of avenanthramide intake in humans. Food Chemistry, 253, 93-100. https://doi.org/10.1016/j.foodchem.2018.01.138

Prugar, J. et al. (2008). The quality of plant products on the threshold of the $3 \mathrm{rd}$ millennium. Research Institute of Brewing and Malting in cooperation with the Commission for the Quality of Plant Products, 327. ISBN 978-808-6576-282

Pulido, O. M., Gillespie, Z., Zarkadas, M., Dubois, S., Vavasour, E., Rashid, M.,

Godefroy, S. B. (2009). Chapter 6 Introduction of Oats in the Diet of Individuals with Celiac Disease. Advances in Food and Nutrition Research, 235285. https://doi.org/10.1016/s1043-4526(09)57006-4

Rieder, A., Holtekjølen, A. K., Sahlstrøm, S., \& Moldestad, A. (2012). Effect of barley and oat flour types and sourdoughs on dough rheology and bread quality of composite wheat bread. Journal of Cereal Science, 55, 44-52. https://doi.org/10.1016/j.jcs.2011.10.003

Ryan, L., Thondre, P. S., \& Henry, C. J. K. (2011). Oat-based breakfast cereals are a rich source of polyphenols and high in antioxidant potential. Journal of Food Composition and Analysis, 24, 929-934. https://doi.org/10.1016/j.jfca.2011.02.002

Sánchez-Moreno, C., Larrauri, J. A., \& Saura-Calixto, F. (1998). A procedure to measure the antiradical efficiency of polyphenols. Journal of the Science of Food and Agriculture, 76, 270-276. https://doi.org/10.1002/(sici)10970010(199802)76:2<270::aid-isfa945>3.0.co;2-9

Särkijärvi, S., \& Saastamoinen, M. (2006). Feeding value of various processed oat grains in equine diets. Livestock Science, 100, 3-9. https://doi.org/10.1016/j.livprodsci.2005.11.005

Shah, A., Masoodi, F. A., Gani, A., \& Ashwar, B. A. (2016). Newly released oat varieties of Himalayan region:Techno-functional, rheological, and nutraceutical properties of flour. $L W T, 70,111-118$. https://doi.org/10.1016/j.lwt.2016.02.033 Shewry, P. R. (1999). Avenins: The Prolamins of Oats. Seed Proteins, 79-92. https://doi.org/10.1007/978-94-011-4431-5_4

Shotwell, M. A. (1999). Oat Globulins. Seed Proteins, 389-400. https://doi.org/10.1007/978-94-011-4431-5 16

Singleton, V. L. \& Rossi, J. A. (1965). Colorimetry of total phenolics with phosphomolybdic - phosphotungstic acid reagents. American Journal of Enology and Agricultural, 6, 144-158.

Sterna, V., Zute, S., \& Brunava, L. (2016). Oat Grain Composition and its Nutrition Benefice. Agriculture and Agricultural Science Procedia, 8, 252-256. https://doi.org/10.1016/j.aaspro.2016.02.100

STN 56 0053: 1986. Determination of vitamin A and its provitamins. Praha: ÚNN, 1986

Størsrud, S., Olsson, M., Arvidsson Lenner, R., Nilsson, L. Å., Nilsson, O., \& Kilander, A. (2003). Adult coeliac patients do tolerate large amounts of oats. European Journal of Clinical Nutrition, 57, 163-169. https://doi.org/10.1038/sj.ejcn.1601525 
Valle, F. R., Villanueva, H., Reyes-Govea, J., Escobedo, M., Bourges, H., Ponce, J., \& Munoz, M. J. (1981). Development, Evaluation and Industrial Production of a Powdered Soy-Oats Infant Formula Using a Low-Cost Extruder. Journal of Food Science, 46, 192-197. https://doi.org/10.1111/j.1365-2621.1981.tb14562.x Van den Broeck, H., Londono, D., Timmer, R., Smulders, M., Gilissen, L., \& van der Meer, I. (2015). Profiling of Nutritional and Health-Related Compounds in Oat Varieties. Foods, 5, 2. https://doi.org/10.3390/foods5010002

Varga, M., Jójárt, R., Fónad, P., Mihály, R., \& Palágyi, A. (2018). Phenolic composition and antioxidant activity of colored oats. Food Chemistry, 268, 153161. https://doi.org/10.1016/j.foodchem.2018.06.035

Varma, P., Bhankharia, H., \& Bhatia, S. (2016). Oats: A multi-functional grain. Journal of Clinical and Preventive Cardiology, 5, 9 https://doi.org/10.4103/2250-3528.183984

Vollmanová, A., Musilová, J., Urminská, D. et al. 2018. Food chemistry. Nitra Slovak University of Agriculture, 543. ISBN: 978-80-552- 1814-4

VURV. (2017). Registered varieties bred at Research and Breeding Stations of the Piešt'any Plant Research Institute. Available at https://www.vurv.sk/aktivity/registrovane-odrody/v-slovenskej-republikeregistrovane-odrody-vyslachtene-na-vyskumno-slachtitelskych-staniciach-vurvpiestany

Walters, M., Lima Ribeiro, A. P., Hosseinian, F., \& Tsopmo, A. (2018). Phenolic acids, avenanthramides, and antioxidant activity of oats defatted with hexane or supercritical fluid. Journal of Cereal Science, 79, 21-26. https://doi.org/10.1016/j.jcs.2017.09.010

Wang, P., Chen, H., Zhu, Y., McBride, J., Fu, J., \& Sang, S. (2014). Oa Avenanthramide-C (2c) Is Biotransformed by Mice and the Human Microbiota into Bioactive Metabolites. The Journal of Nutrition, 145, 239-245. https://doi.org/10.3945/jn.114.206508

Youssef, M. K. E., Nassar, A.G., EL-Fishawy, A. \& Mostafa, M. A. (2016) Assessment of proximate chemical composition and nutritional status of wheat biscuits fortified with oat powder. Assiut Journal of Agricultural Sciences, 47 83-94. https://doi.org/10.21608/ajas.2016.2071

XLSTAT 2020: Data analysis and statistical solution for Microsoft excel. ADDINSOFT Corporation (2020).

Zhang, D., Moore, W. R., \& Doehlert, D. C. (1998). Effects of Oat Grain Hydrothermal Treatments on Wheat-Oat Flour Dough Properties and Breadbaking Quality. Cereal Chemistry Journal, 75, 602-605. https://doi.org/10.1094/cchem.1998.75.5.602

Zhu, F. (2018). Anthocyanins in cereals: Composition and health effects. Food
Research
International,
109
232-249.

https://doi.org/10.1016/j.foodres.2018.04.015 